\title{
O discurso de ódio no jornalismo online: análise de comentários nas redes sociais do Portal Imirante.com
}

\author{
Discurso de odio en el periodismo en línea: análisis de \\ comentarios en las redes sociales de Imirante.com
}

\section{The hate speech in online journalism: analysis of comments on the social networks of Imirante.com Portal}

\author{
Cláuberson Correa Carvalho¹, Adriano Silva Soares²
}

\begin{abstract}
RESUMO: Esta pesquisa pretende analisar o discurso de ódio materializado em comentários nas redes sociais do Portal Imirante.com. Parte-se de pressupostos teóricos da Análise do Discurso (FERNANDES 2008; ORLANDI, 2013; PINTO, 2002), para compreender noções como discurso, formação discursiva e ideologia; e do jornalismo online (BARBOSA, 2007; LEAL, 2011; RECUERO, 2009, 2011), para entender 0 funcionamento dos sites de redes sociais nas plataformas digitais de comunicação. $O$ corpus compreende as seis publicações do Portal Imirante.com com maior engajamento em setembro de 2018. Os resultados apontam que o discurso de ódio manifesta relações de diálogo com outros discursos socialmente construídos: político, religioso, machista e homofóbico.
\end{abstract}

PALAVRAS-CHAVE: Discurso de ódio. Jornalismo online. Redes sociais.

RESUMEN: Esta investigación pretende analizar el discurso de odio materializado en los comentarios en las redes sociales de Portal Imirante.com. Comienza con suposiciones teóricas del análisis del discurso (FERNANDES 2008; ORLANDI, 2013; PINTO, 2002), para comprender nociones como el discurso, la formación discursiva y la ideología; y periodismo en línea (BARBOSA, 2007; LEAL, 2011; RECUERO, 2009, 2011), para comprender el funcionamiento de los sitios de redes sociales en las plataformas de comunicación digital. El corpus comprende las seis publicaciones de Portal Imirante.com

\footnotetext{
${ }^{1}$ Doutorado em Ciências Sociais pela Universidade Federal do Maranhão. Professor dos Cursos de Jornalismo e Publicidade e Propaganda da Universidade CEUMA. E-mail: claubersoncc@gmail.com.

${ }^{2}$ Bacharel em Jornalismo pela Universidade CEUMA. Jornalista do Grupo Mirante. E-mail: adrianosoaresdt@gmail.com.
} 
O discurso de ódio no jornalismo online: análise de comentários nas redes sociais do

Portal Imirante.com

más comprometidas de septiembre de 2018. Los resultados muestran que el discurso de odio manifiesta relaciones dialógicas con otros discursos construidos socialmente: políticos, religiosos, sexistas y homofóbicos.

PALABRAS CLAVE: Discurso de odio. Periodismo en línea. Redes sociales.

ABSTRACT: This research intends to analyze the hate speech materialized in comments in the social networks of Imirante.com Portal. It is based on the theoretical assumptions of Discourse Analysis (FERNANDES 2008; ORLANDI, 2013; PINTO, 2002), to understand notions such as discourse, discursive formation and ideology; and online journalism (BARBOSA, 2007; LEAL, 2011; RECUERO, 2009, 2011), to understand the functioning of social networking sites on digital communication platforms. The corpus comprises the six publications of Imirante.com Portal with greater engagement in September 2018. The results indicate that the hate speech manifests dialogic relations with other socially constructed discourses: political, religious and homophobic.

KEYWORDS: Hate speech. Online journalism. Social networks.

\section{Introdução}

O século XX teve como um dos seus principais marcos o surgimento da Rede Mundial de Computadores, popularmente conhecida por Internet. Com o passar dos anos, essa ferramenta se aperfeiçoou e ganhou mais adeptos e mais mecanismos que predem os indivíduos nesse novo mundo virtual. Pode-se dividir a história em antes e depois da internet, que se tornou um espaço de trabalho, diversão e, mais recentemente, de várias discussões de cunho social e político (RECUERO, 2011).

Os atuais e tão populares Sites de Redes Sociais (SRS) estão dentro de um ciberespaço que permite de uma maneira livre, porém que implica em punições, a propagação de ideias que por vezes servem de subsídio para a reafirmação de muitos preconceitos que foram incorporados ao logo da vida dos indivíduos responsáveis pelos insultos.

Nesse contexto, toma-se como objeto de estudo o portal de notícias Imirante.com, principal portal jornalístico do Maranhão. Pretende-se analisar o discurso de ódio evocado em suas redes sociais, mais especificamente em 
O discurso de ódio no jornalismo online: análise de comentários nas redes sociais do

Portal Imirante.com

comentários de publicações no Instagram. Verifica-se que há uma tentativa do público em impor pontos de vista, usando de uma plataforma de grande alcance, para desqualificar conceitos e preceitos de outras pessoas que pensam diferente.

Este estudo permite perceber que questões de gêneros, raça, orientação sexual e aspectos sociais são temas que mais geram engajamento dos haters em seus discursos odiosos. Por isso, recorre-se às pesquisas da Análise do Discurso (FERNANDES, 2008; ORLANDI, 2013), doravante AD, para compreender a constituição discursiva dos dizeres e, principalmente, as relações interdiscursivas que estabelecem com outros campos sociais. Defende-se aqui que o discurso de ódio se manifesta numa relação dialógica com outros discursos socialmente construídos.

O corpus da pesquisa compreende as seis publicações com maior engajamento no Instagram do Portal Imirante.com, em setembro de 2018 (período aleatoriamente escolhido para coleta do material). Por engajamento, considera-se o maior número de interações, que são quantificadas a partir do número de curtidas e comentários em cada publicação. A tabela seguinte apresenta as publicações analisadas.

Tabela 1 - Lista de publicações selecionadas

\begin{tabular}{|c|l|c|c|}
\hline DATA & \multicolumn{1}{|c|}{ TÍTULO } & CURTIDA & COMENTÁRIO \\
\hline $06 / 09 / 18$ & $\begin{array}{l}\text { Jair Bolsonaro foi atingido no fígado, pulmão e } \\
\text { intestino, relata filho do presidenciável. Após } \\
\text { cirurgia, quadro do candidato é estável. }\end{array}$ & 1.828 & 235 \\
\hline $04 / 09 / 18$ & $\begin{array}{l}\text { Nova decisão do TSE veta propaganda eleitoral na } \\
\text { TV com Lula candidato. }\end{array}$ & 1.147 & 344 \\
\hline $06 / 09 / 18$ & $\begin{array}{l}\text { Jair Bolsonaro é operado após levar facada em } \\
\text { Minas Gerais. Há suspeita de lesão no fígado e na } \\
\text { alça intestinal; filho do candidato afirma que o pai } \\
\text { levou seis pontos }\end{array}$ & 3.420 & 513 \\
\hline $03 / 09 / 18$ & $\begin{array}{l}\text { Pabllo Vittar rompe com grife de sapatos que } \\
\text { declarou apoio à Jair Bolsonaro. Além de Vittar, } \\
\text { outros artistas também se posicionaram sobre o } \\
\text { caso. }\end{array}$ & 2.574 & 164 \\
\hline $08 / 09 / 18$ & $\begin{array}{l}\text { Fim do casamento de Anitta e Thiago Magalhães } \\
\text { choca internet. }\end{array}$ & 1.882 & 104 \\
\hline $09 / 09 / 18$ & $\begin{array}{l}\text { Em cerimônia íntima, William Bonner casa com } \\
\text { fisioterapeuta Natasha Dantas. O casamento } \\
\text { ocorreu nesse sábado (8), em São Paulo. }\end{array}$ & 4.274 & 52 \\
\hline
\end{tabular}

Fonte: Autores. 


\section{Discussão Teórica}

Nesta seção, procede-se à discussão teórica dos principais conceitos que fundamentam esta análise. Inicialmente, apresentam-se considerações sobre a noção de discurso e seus entrelaçamentos com as redes de sentido e com a ideologia (FERNANDES, 2008; ORLANDI, 2013; PINTO, 2002); em seguida, delineia-se a noção de redes sociais relacionada aos processos de interação nas plataformas digitais (BARBOSA, 2007; LEAL, 2011; RECUERO, 2009).

\section{A noção de discurso}

Tomando o discurso com o elemento de mediação, é possível compreender as transformações dos mais diversos conceitos, do homem e da sua realidade. A AD trabalha com significações, ou seja, com a produção de sentidos de elementos e situações que permeiam a vida dos indivíduos, enquanto membros de um grupo, seja de qual segmento seja, principalmente do social (ORLANDI, 2013).

Por isso, para o analista de discurso - que é considerado um "detetive sociocultural" (PINTO, 2002) - encontrar as "regularidades da linguagem", é necessário relacionar a linguagem com elementos externos (ORLANDI, 2013). Esse analista tem como prática e objetivo, durante o processo de análise, interpretar a fundo vestígios que podem servir de subsídio para uma contextualização que Pinto (2002) classifica em três níveis ou contextos: situacional imediato, institucional e o contexto sociocultural. Sendo assim, os estudos do discurso levam em consideração o sentido dos fatores de acordo com a dimensão de tempo e espaço das práticas humanas.

Por meio do discurso, é possível compreender a relação entre a língua e ideologia. Entretanto, a definição de "discurso" distancia-se da forma como o esquema da comunicação classifica seus elementos primordiais, onde se define o que é mensagem. A saber, esse esquema é composto por emissor, receptor, código, referente e mensagem (ORLANDI, 2013). Dessa maneira, o discurso não 
O discurso de ódio no jornalismo online: análise de comentários nas redes sociais do

Portal Imirante.com

é apenas um processo de transmissão de informações, mas sim algo mais complexo que envolve os processos que identificam o sujeito, assim como argumentação, subjetivação e construção da realidade.

Sendo assim o discurso, de acordo com Orlandi (2013), pode ser definido como o "efeito de sentidos entre locutores". Com relação à produção de sentidos, no discurso, as palavras não são fixas. Os sentidos se fazem a partir dos lugares que são ocupados pelos indivíduos que estão no processo de interlocução, ou seja, uma mesma palavra pode ter várias significações, de acordo com o lugar socioideológico de quem a está empregando (FERNANDES, 2008), em outras palavras: o lugar de fala.

Dessa forma, a análise é tida como um elemento que deixa mais evidentes os sentidos do discurso, levando, mais uma vez, em consideração as condições sociais, históricas e ideológicas do processo de produção (FERNANDES, 2008), que, de acordo com Orlandi (2013), de maneira fundamental, compreendem os sujeitos e as situações.

Outro fator que compreende a produção do discurso é a memória, pois a forma como ela ativa as condições de produção é de grande importância nesse contexto. É por meio da memória que se entra na parte da história. A partir dessa relação é possível compreender a produção de acontecimentos, como, por exemplo, a leitura das cores enquanto produto semiológico: associar o preto ao fascismo e o vermelho ao comunismo. Essas relações ideológicas e de memória afetam os indivíduos até mesmo no seu posicionamento político (ORLANDI, 2013).

Uma importante característica da memória refere-se a sua relação com o discurso. Entretanto, nesse contexto, ela é tida como um interdiscurso ou memória discursiva. Isso tem a ver com a maneira como o sujeito se significa em uma dada situação, e envolve, por exemplo, os lugares ocupados pelos sujeitos que estão no processo de interlocução (FERNANDES, 2008). Nesse ponto, Orlandi (2013) diferencia interdiscurso e intertexto. O primeiro toma como fundamento todo o conjunto de formulações feitas pelo sujeito, mas que já foram esquecidas por ele, porém acabam determinando o que esse indivíduo diz. Em outras 
O discurso de ódio no jornalismo online: análise de comentários nas redes sociais do

Portal Imirante.com

palavras, para que as palavras ditas pelo sujeito tenham sentido, é necessário que elas já façam sentido posteriormente. Já no intertexto, o esquecimento não é algo estruturante, como é para o interdiscurso. 0 intertexto se restringe "a relação de um texto com outros textos" (ORLANDI, 2013). Porém, de acordo com Fernandes (2008), ambos despertam as relações de sentidos. Esse sentido é tomado como um efeito de sentido que ocorre no processo de enunciação entre dois interlocutores $(A+B)$, tendo $A$ e $B$ representando os diferentes sujeitos em interlocução, em específicos espaços socioideológicos.

Na perspectiva da $A D$, conforme Fernandes (2008), para se iniciar uma reflexão sobre o discurso, alguns conceitos chaves precisam ser compreendidos. São eles: sentido, enunciação, ideologia, condições de produção e sujeito discursivo. O primeiro tem a ver com o impacto - ou efeito - que o sentido causa entre os sujeitos em enunciação. Esse conceito é integrante da noção de discurso. Uma mesma palavra, por exemplo, pode ter sentidos diferentes, de acordo com a ideologia dos sujeitos, que é construída a partir da realidade política e social em que estão inseridos. Ou seja, do lugar histórico-social de onde é feita a enunciação. Sendo assim, o sentido e sua produção, é parte das atividades sociais dos indivíduos (FERNANDES, 2008, p. 18). No discurso, as palavras não possuem um sentido fixo. Eles são flexíveis e variados, de acordo com o ambiente social que os sujeitos estão inseridos, conforme já foi mencionado anteriormente.

Já a enunciação leva em consideração a posição ideológica na prática de enunciar, tomando como critério importante o lugar sócio-histórico-ideológico de onde os sujeitos falam e marcam o momento e o ato de dizer em si. Esse lugar histórico-social é um dos elementos que envolvem o contexto e a situação.

O lugar histórico-social em que os sujeitos enunciadores de determinado discurso se encontram envolve o contexto e a situação e intervém a título de condições de produção do discurso. Não se trata da realidade física e sim de um objeto imaginário socioideológico (FERNANDES, 2008, p. 18).

A enunciação é o fator que caracteriza a realidade da língua. Essa realidade é necessariamente de uma natureza classificada como social. Ela (enunciação) é 
O discurso de ódio no jornalismo online: análise de comentários nas redes sociais do Portal Imirante.com

tida como uma imitação do diálogo social. Dessa forma, a enunciação é caracterizada como o produto concebido a partir de dois sujeitos socialmente organizados.

A ideologia trata da concepção de mundo onde o sujeito está inserido. As condições de produção tomam como fator os aspectos históricos, sociais e ideológicos. A ideologia revela, de maneira igual, as posições de grupos sobre um mesmo tema, que é materializado sobre o discurso. Trata-se de um elemento que marca as diferentes posições do sujeito. Dessa maneira, ela é algo fundamental para a compreensão da noção do discurso (FERNANDES, 2008).

Por último, o sujeito discursivo vê o indivíduo como um ser polifônico, ou seja, é constituído por uma multiformidade de discursos (FERNANDES, 2008). Como já falado anteriormente, na $A D$, o sujeito não é visto de modo isolado, que possui uma existência individualizada no mundo e sim a conjuntura social em que está inserido. Ainda de acordo com Fernandes (2008), para compreender o sujeito discursivo é necessário entender as vozes sociais que estão presentes nele.

Ainda falando de sentido, Orlandi (2013) observa que ele não existe em si, mas as posições ideológicas que são impostas em jogo, no processo sóciohistórico em que são produzidas as palavras, é que o vão determinar. Tida como polêmica, a formação discursiva é um elemento básico da $A D$, pois, através dela, é possível compreender todo o processo de produção dos sentidos, que requer um estudo bem apurado. Além disso, por meio dessa formação, o analista consegue compreender a relação dessa produção de sentidos com a ideologia, dando ainda a possibilidade de ter uma "regularidade no funcionamento do discurso" (ORLANDI, 2013, p. 10).

Dessa maneira, é possível perceber que toda formação discursiva apresenta, dentro de si, diversificados discursos, que é o já mencionado interdiscurso. Esse elemento é algo que vem de momentos históricos distintos e de variados lugares sociais (FERNANDES, 2008). Essa formação discursiva pode ser definida, segundo Orlandi (2013), como o que em certa formação ideológica determina o que pode e o que deve ser dito. 
O discurso de ódio no jornalismo online: análise de comentários nas redes sociais do

Portal Imirante.com

Em se tratando de discurso de ódio, os autores concordam corresponder a uma forma de insulto. Para Brugger (2007), esse tipo de discurso se utiliza de características pessoais para potencializar o efeito depreciativo sobre alguém. Sarmento (2006) cita idade, raça, escolaridade, orientação sexual, classe social como indicadores potenciais do discurso de ódio.

Como consequência, esse discurso promove ideais discriminatórios racistas, sociais e religiosos (MEYER-PFLUG, 2009). Conforme Diaz (2011), o discurso de ódio é muito mais que antipatia ou não reconhecimento por determinado grupo: corresponde à hostilização. Brugger (2007) fala em insultar, assediar e intimidar. Daí se tratar de uma manifestação efetiva de ódio contra alguém.

\section{A noção de redes sociais}

Um fenômeno ainda recente vem mudado a forma de o homem se comunicar com o mundo: a chamada Comunicação Mediada pelo Computador (CMC). Além de permitir aos seres humanos se comunicarem de maneira mais ampla, esse processo agilizou os meios de conversação mediados, amplificando assim a capacidade de conexão entre os interlocutores.

Por meio desse novo mecanismo, as chamadas Redes Sociais Mediada por Computador (RSMC) foram criadas dentro da internet. Essas redes não só conectam computadores, mas também smartphones, elas vão além disso: conectam pessoas (RECUERO, 2009).

As redes sociais como objeto de estudo não são algo novo para a ciência. Desde o século XX muitos estudiosos se debruçam em analisar as sociedades por meio do estudo de agrupamentos em redes. Com o advento da internet, houve a possibilidade de os atores dos processos sociais interagirem com outros atores, deixando pistas, na rede mundial de computadores, que permitem compreender e analisar seus comportamentos e padrões. 
O discurso de ódio no jornalismo online: análise de comentários nas redes sociais do

Portal Imirante.com

É o surgimento dessa possibilidade de estudo das interações e conversações através dos rastros deixados na Internet que dá novo fôlego à perspectiva de estudo de redes sociais, a partir do início da década de 90 . É, neste âmbito, que a rede como metáfora estrutural para a compreensão dos grupos expressos na Internet é utilizada através da perspectiva de rede social (RECUERO, 2009, p. 24).

A definição de rede social é dada como um conjunto formado por dois elementos básicos: atores e suas conexões. O primeiro elemento são as pessoas, instituições ou, como Recuero (2009) chama, os "nós da rede". Já as conexões são compreendidas como as interações ou os laços sociais. Dessa maneira, uma rede é tida como uma metáfora que tem como objetivo a observação de padrões de conexão que são estabelecidos entre os atores do processo social.

Já na internet o estudo das redes sociais se concentra na análise da problemática do surgimento das estruturações sociais, levando em consideração seu tipo e a composição, por meio do processo comunicativo mediado pelo computador ou outro dispositivo. Além disso, permite compreender como essas interações que são mediadas conseguem produzir um fluxo informacional e "troca sociais que impactem essas estruturas" (RECUERO, 2009, p. 24). Entretanto, para o estudo dessas redes, é necessário analisar os elementos e os processos dinâmicos que as permeiam.

O primeiro elemento do processo de análise das redes sociais são os atores, como já mencionado anteriormente. Nada mais são que as pessoas que estão envolvidas na rede que está sendo analisada. O principal objetivo desses atores é de moldar as estruturas sociais, por meio das interações e formação de laços sociais.

Os atores das redes sociais na internet são definidos de uma maneira distinta, por conta do distanciamento entre esses protagonistas, dentro do processo. Sendo assim, por conta desse distanciamento, que é a principal característica da CMC, os atores não são discernidos de maneira imediata. Por isso, são usadas representações dos atores sociais ou ainda, de acordo com Recuero (2009), com as construções identitárias do ciberespaço. De maneira 
O discurso de ódio no jornalismo online: análise de comentários nas redes sociais do

Portal Imirante.com

mais prática: os atores podem ser representados por um Facebook, Twitter, Instagram.

A compreensão de como os atores constroem os espaços onde se expressam é de grande importância para entender um outro aspecto: como as conexões são formadas. É por meio dessas análises que são gerados os padrões de conexões construídas pelos atores. No ciberespaço muitas características desses processos podem ser vistas. No Facebook, por exemplo, é nítida a individualização e como os perfis são construídos, de acordo com cada ator social.

Sobre as conexões das redes sociais, as proposições de Recuero (2009), de maneira mais ampla, apontam que são formadas a partir dos laços sociais, que são gerados a partir da interação social entre os atores inseridos no processo.

Os Sites de Redes Sociais (SRS) são tidos como um processo de apropriação pelos atores sociais das ferramentas de comunicação mediada por computadores. Dessa maneira, os SRS são os locais utilizados para que as redes sociais possam ser materializadas na internet.

Ainda de acordo com as definições propostas por Recuero (2009), os SRS têm como principal foco expor publicamente as redes sociais em que os atores estão inseridos. Convém ressaltar que eles não representam obrigatoriamente redes que são independentes entre si. Os atores podem usar diversos SRS, mas cada qual com uma finalidade distinta.

Um fator importante a ser levado em consideração sobre os SRS é um elemento chamado visibilidade. Isso quer dizer que esses sites de redes sociais têm deixado os atores ainda mais conectados, ou seja, há maior visibilidade dos nós sociais (laços sociais). Recuero (2009) chama atenção para o "gerenciamento de grupos sociais". Nesse caso, a compreensão é que os sites de redes sociais podem servir de auxílio aos atores e conseguir fazer o gerenciamento dos grupos/nichos sociais.

Ainda sobre Redes Sociais na internet, é importante apontar o fator popularidade, que está intrinsicamente ligado à audiência. De acordo com Recuero (2009), esse fator está ligado à posição que um certo ator tem dentro da sua rede social, pois se trata de um nó social mais centralizado e popular, pelo 
O discurso de ódio no jornalismo online: análise de comentários nas redes sociais do

Portal Imirante.com

fato de muitas pessoas estarem conectadas a ele. Por isso, esse ator consegue ter um poder de persuasão mais forte que outros nós que estão inseridos na mesma rede.

Outros fatores também estão ligados à popularidade. Entre eles, o número de comentários e os níveis de audiência que cada página de site de rede social tem, assim como o número de visitas e quantidade de links.

\begin{abstract}
A popularidade também não é relacionada com autoridade, mas, simplesmente, com algum tipo de reputação (boa ou ruim, por exemplo). Um blog pode ser popular porque é ruim, porque é engraçado, porque é crítico etc., e não necessariamente porque 0 blogueiro tem autoridade. A popularidade pode ser, assim, uma medida quantitativa da localização do nó na Rede (RECUERO, 2009, p. 113).
\end{abstract}

Por fim, o último valor é a autoridade que, também de acordo com Recuero (2009), se trata da grande influência que um nó na rede social possui. Essa autoridade tem a ver também com a reputação, entretanto, não se resume só a ela. O valor autoridade não é decorrente apenas de elementos como o capital social relacional, mas, de maneira igual, ao capital social cognitivo.

\title{
A interação nas redes sociais
}

A interação no jornalismo digital adquire papel decisivo nos denominados cibermeios (BARBOSA, 2007). Nesta pesquisa, discute-se o conceito de interação na perspectiva de Primo (1998), para quem interação implica "ação entre", na qual os interagentes (portais e leitores) estabelecem uma relação a partir das potencialidades oferecidas pela mediação das ferramentas e do ciberespaço.

A incorporação das redes sociais à rotina jornalística, segundo Brambilla (2005), pode ser analisada em três instâncias: no âmbito da apuração, da veiculação de conteúdos e na recepção da audiência, ou seja, na resposta direta do público a partir da mensuração de dados.

Para Barbosa (2007), o Jornalismo Digital de Base de Dados, ou modelo JSBD, tem na base de dados a estrutura e organização, apresentação e circulação 
O discurso de ódio no jornalismo online: análise de comentários nas redes sociais do

Portal Imirante.com

de conteúdos de natureza jornalística no ciberespaço. Funcionalidades como conformar padrões novos para a construção das peças informativas e habilitar o uso de metadados para análise de informações e extração de conhecimento, seja por meio de técnicas estatísticas ou métodos de visualização e exploração como o data mining (BARBOSA, 2007).

No cenário tecnológico e informacional contemporâneo, essas funcionalidades passam a integrar a criação, a manutenção, a atualização, a disponibilização e a circulação de produtos jornalísticos digitais. A exemplo, o uso de metadados para a obtenção de informações e conhecimentos sobre o público e seus interesses, os quais, por sua vez, vão impactar diretamente as práticas do jornalismo digital. Considera-se a estética presente no jornalismo digital como como uma perspectiva reveladora dos modos de autenticação do jornalismo e de sua relação com o público (LEAL, 2011).

Levando em consideração uma audiência cada vez "nômade" do comportamento público dentro da rede, o jornalismo e, principalmente, os profissionais envolvidos nesse processo precisam de meios para conseguir prender esse leitor que hoje é livre para escolher ver o que quiser e a hora em que quiser, em um processo considerado móvel e fragmentado (LEAL, 2011).

Dessa forma, os estudos de estética dentro da comunicação não veem os produtos comunicacionais, no caso a notícia, como objetos de arte, mas sim a apropriação dos "modos de fazer", levando em consideração a dimensão sensível desse produto comunicacional (LEAL 2011). O portal Imirante.com, por exemplo, faz uso do Gloogle Analytic ${ }^{3}$ para que sejam observados os dados de acessos à página. Além disso, observa-se qual a notícia mais lida e quanto tempo cada internauta ficou online no portal. O monitoramento das redes sociais, desenvolvido pelos jornalistas responsáveis pelo portal, também pode definir a disposição do material jornalístico na capa do portal. Assuntos com os maiores índices de acessos e que apresentam uma boa repercussão nas redes sociais

\footnotetext{
${ }^{3}$ O Google Analytics é uma plataforma do Google que mapeia os dados de visualização de uma página da web. Esse recurso é muito utilizado pelos portais de notícias para ter um feedback de suas publicações.
} 
O discurso de ódio no jornalismo online: análise de comentários nas redes sociais do

Portal Imirante.com

ganham posição de destaque. Assim, é possível compreender parcialmente a rotina produtiva do portal Imirante e como ocorre o monitoramento das redes sociais do veículo de comunicação em questão. As ferramentas de web permitem ao redator ter um controle das ações do portal dentro da internet.

\section{Análise do corpus}

Nesta seção, levando em consideração todas as definições e argumentações já citadas ao longo deste trabalho, procede-se às análises dos comentários das publicações do portal Imirante.com, no Instagram. Nesse SRS, o veículo possui quase 240 mil seguidores. Ao longo do dia, cerca de 15 publicações são feitas no feed do Imirante.

Dessa forma, a análise de comentários será feita de forma categorizada. Os discursos são categorizados de acordo com seu fundamento ideológico, ou seja, como homofóbico, racista, religioso, conforme Orlandi (2013) chama de tipologias. São tomadas como fundamentação as proposições de Ezequiel e Cioccari (2017), Leal (2011), Dantas e Pereira Neto (2015) e Dejavite (2007).

\section{Discurso político}

Nesta seção, procede-se à análise dos comentários nas publicações que constituem o corpus desta pesquisa. A primeira categoria refere-se ao discurso político. Para sistematizar a discussão, organizam-se os enunciados conforme as postagens onde foram localizados.

Tabela 2 - Enunciados 1, 2 e 3

TÍTULO: Jair Bolsonaro foi atingido no fígado, pulmão e intestino, relata filho do presidenciável. Após cirurgia, quadro do candidato é estável. Acesse o Imirante.com e saiba mais.
E1: "O teu castigo vem. Pode esperar que terão retorno com uma bala na cabeça, seu demônio. "

E2: "Pena que não foi na língua, pra parar de falar merda"

E3: "Analfabeto de tudo, até da religião. Acredito que você é um idiota e 
O discurso de ódio no jornalismo online: análise de comentários nas redes sociais do

Portal Imirante.com

Fonte: Autores.

incompetente de tudo. Infeliz é a mulher que se envolver com você, demônio"

No E1, o sujeito se mostra indignado com o ataque ao candidato Jair Bolsonaro. O discurso é também representado por outros sujeitos, no qual é possível perceber o tom de revolta, atrelado à liberdade de expressão, sendo esse um direito assegurado por vários tratados, entre eles a Declaração Universal dos Direitos Humanos e a própria Constituição Brasileira.

Ainda sobre o E1, é possível categorizar o discurso como sendo de um viés religioso. A influência religiosa no Brasil ainda é muito forte. $\mathrm{O}$ Brasil é um país historicamente católico. Essa religião já representou cerca de $90 \%$ da população brasileira. Por isso, muitas pessoas ainda vivem em um religiosismo de intolerância. Dessa maneira, a influência dos discursos religiosos ainda é muito forte nos processos sociais.

Na contemporaneidade, essa importância se estende principalmente pelo fato de a religião ser responsável pela propagação de valores morais e éticos dentro da sociedade. Ademais, é cada vez mais atuante seu papel na formação da identidade de um determinado povo (ASSIS; MELO, 2017, p. 85).

Sendo assim, a demonização, que é a atribuição de caráter demoníaco a alguém ou algo, tem se tornado cada vez mais frequente. Nas redes sociais, no caso do Instagram do portal Imirante, esse processo é recorrente, tomando como exemplo o $\mathrm{E} 1$, em que o internauta demoniza o autor do ataque ao então candidato Jair Bolsonaro. Esse mesmo internauta deseja a morte, com um tiro na cabeça para quem atacou o político.

Por isso, nesse ponto, fala-se em interdiscursividade, conforme Orlandi (2013). Acontece que há o entrecruzamento dos discursos político e religioso, de forma que ambos são evocados, mesmo que involuntariamente, pelos sujeitos enunciadores. Em E1, o sujeito enuncia a partir de uma formação discursiva que evoca tanto dizeres políticos (ataques à autoridade política brasileira) quanto religiosos (na caracterização do político como "demônio"). 
O discurso de ódio no jornalismo online: análise de comentários nas redes sociais do

Portal Imirante.com

Pensando a formação discursiva como o que pode ser dito (ORLANDI, 2013), a escolha da palavra "demônio" como caracterizador do objeto do discurso (a personagem Bolsonaro) retoma uma série de outros sentidos já socialmente cristalizados no discurso religioso cristão: maldade, crueldade, entre outros predicativos de semântica negativa. Por isso, "demônio" assume inclinações semânticas conforme a formação discursiva em que gerado.

Um outro discurso odioso é visto nos E2 e E3. Entretanto, o alvo dos comentários muda: deixa de ser o autor do ataque e passa a ser o atacado. As eleições presidenciais de 2018, sem dúvidas, afloraram os instintos mais indignados dos brasileiros. Muitos aproveitaram esse momento para de certa forma expor aquilo que pensam e anseiam.

Um dos discursos de Jair Bolsonaro durante o período eleitoral 2018 foi o da legalização do porte de arma. Essa fala, assim como tantas outras dele, ganhou repercussão e dividiu os brasileiros em contra e a favor. Em E2 e E3, é possível perceber a revolta dos usuários com relação aos posicionamentos de Bolsonaro.

A exemplo disso, no E2, o internauta lamenta que a facada não tenha atingido língua do então presidenciável, ou seja, um anseio motivado pelas declarações de Bolsonaro durante as eleições, que tinham como principais alvos mulheres, negros e LGBTs. Sendo assim, o E3 pode ser visto como um desejo de calar o candidato, visto o impacto que seus posicionamentos causam no público receptor. Durante o período analisado, foi possível perceber que os discursos políticos partiram de dentro das redes sociais e em muitos casos não foram feitos pelos candidatos, e sim pela grande massa, que está presente nos SRS.

Ainda falando sobre o E3, o comentário também remete à demonização do candidato Jair Bolsonaro, que é o alvo principal da publicação. O discurso do E3 tem uma visão individualista. Por esse aspecto, volta-se a falar sobre liberdade de expressão, entretanto, ela não é absoluta. De acordo com Ezequiel e Cioccari (2017), essa liberdade não pode ser usada para que a intolerância e o preconceito sejam praticados, sejam de que natureza forem. Além disso, não devem servir de subsídio para uma aparente defesa que caracteriza uma postura criminosa. 
O discurso de ódio no jornalismo online: análise de comentários nas redes sociais do

Portal Imirante.com

Tabela 3 - Enunciados 4 e 5

TÍTULO: Nova decisão do TSE veta propaganda eleitoral na TV com Lula candidato.
E4: "Um vagabundo desse tinha que passar o resto da vida era na cadeia, isso sim! Nojo desse lixo de ser humano um bosta"

E5: "Nunca vi presidiário se candidatar a presidente. " Coisas que só acontecem no Brasil"

Fonte: Autores.

Outra publicação que também teve comentários odiosos com cunho político foi a que noticiou a decisão do Tribunal Superior Eleitoral (TSE) de vetar a propaganda eleitoral na TV com o ex-presidente Lula. No E4, uma das principais características do discurso de ódio é evidenciada, que é infringir a dignidade humana.

O ex-presidente Lula se entregou à Polícia Federal no dia sete de abril de 2017, após ser condenado em segundo grau na Lava Jato por corrupção passiva e lavagem de dinheiro. Com essa polêmica, aflorou-se uma onda de antipetismo, confrontando com o Lulismo, em todo o Brasil, durante a pré-campanha e na própria campanha eleitoral 2018.

Os antipetistas, a exemplo do que pode ser visto em E4 e E5, fazem o uso de palavras ofensivas para se referir ao candidato a quem fazem oposição gratuita. Esse fenômeno ganhou as redes sociais com grandes proporções no último pleito presidencial. Em E5, Lula é tido na condição de presidiário, mesmo após já ter conduzido o país por oito anos. E o discurso ressalta essa condição de presidiário de Lula.

Tabela 4 - Enunciados 6, 7 e 8.

TÍTULO: Jair Bolsonaro é operado após levar facada em Minas Gerais. Há suspeita de lesão no fígado e na alça intestinal; filho do candidato afirma que o pai levou seis pontos.
E6: "Tá vivo?! AFF"

E7: "Engraçado que agora ele é o 'coitadinho' depois de disseminar o ódio de forma gratuita. Parabéns aos acéfalos que defendem esse 'ser'"

E8: "Vombora pae.... sai dessa. Ganha essa merda dessas eleições e bota ORDEM nesse cabaré" 
O discurso de ódio no jornalismo online: análise de comentários nas redes sociais do

Portal Imirante.com

Fonte: Autores.

Na publicação acima, os comentários seguem a linha do discurso de ódio político. O título da postagem direciona para uma notícia que fala sobre a operação que o então candidato Jair Bolsonaro realizou, após sofrer o ataque em Juiz de Fora (MG), durante ato público.

No E6, o sujeito discursivo lamenta o fato de Jair Bolsonaro ainda estar vivo, após o ataque. Um incitamento de ódio, que, de acordo com Rosane Leal Silva et al. (2011), atinge a dignidade, no respeito que cada ser humano deve ao outro de forma mútua. Ainda segundo as proposições de Leal Silva et al. (2011) sobre o discurso de ódio:

\begin{abstract}
No caso do discurso odiento, vai-se além: é atacada a dignidade de todo um grupo social, não apenas a de um indivíduo. Mesmo que este indivíduo tenha sido diretamente atingido, aqueles que compartilham a característica ensejadora da discriminação, ao entrarem em contato com o discurso odiento, compartilham a situação de violação. Produzse o que se chama de vitimização difusa (SILVA et al., 2011, p. 449).
\end{abstract}

Dessa maneira, é possível relacionar a fala de Rosane Leal Silva et al. (2011) com o que pode ser visto nos enunciados da postagem sobre o quadro de saúde do então candidato à presidência da república Jair Bolsonaro. O teor dos comentários tem por intuito atacar a dignidade do político na ordem de seu ofício. Todos os demais comentários dessa publicação, que compartilham da mesa ideologia odiosa, compartilham a situação de violação dos direitos da vítima dos ataques.

Logo em seguida, em E7, o comentário representa Jair Bolsonaro como, sarcasticamente, um "coitadinho", após o ataque sofrido. Além disso, enunciador considera que o que aconteceu com o então candidato foi consequência de um discurso considerado por muitos como severo. Adiante, ainda no E7, o mesmo comentário classifica como acefálicas as pessoas que defendem o então candidato à presidência da República.

Neste caso, assim como em todos os enunciados já analisados, o meio usado para a propagação do discurso de ódio é fundamental para manifestar seus objetivos danosos. Ainda de acordo com Rosane Leal Silva et al. (2011), o 
O discurso de ódio no jornalismo online: análise de comentários nas redes sociais do Portal Imirante.com

discurso se torna mais nocivo quanto maior é o poder de difusão que o seu meio de veiculação possui. No caso da página do Instagram do portal Imirante, a visibilidade que esses comentários podem ganhar é extrema, sabendo que o perfil possui mais de 240 mil seguidores, uma das mais vistas de todo o estado do Maranhão.

Já, no E8, o discurso deseja uma breve recuperação de Jair Bolsonaro para colocar em ordem o "cabaré" com o qual o Brasil é comparado pelo sujeito. No comentário, o sujeito discursivo considera que há uma desordem no país. A definição de cabaré seria uma casa de prostituição, onde há consumo de bebidas alcoólicas e músicas.

Novamente, o discurso de ódio evoca palavras cujos significados pertencem a outras formações discursivas. Dessa vez, "cabaré" é socialmente construído em contextos sexuais. Ressignificando o termo para a formação discursiva do campo político, a intencionalidade do sujeito de E8 é ridicularizar o país, confirmando um dos principais traços constitutivos do discurso de ódio (SILVA et al., 2011).

\section{Discurso homofóbico}

Em um contexto em que a diversidade aflora, o preconceito, a discriminação, a violência e os discursos de ódio, infelizmente, ainda têm espaço. Muitos usam as SRS para despejarem toda a carga odiosa e intolerante, visando ofender e agredir uma pessoa ou grupo diferente daquele do qual faz parte.

Dessa maneira, é possível perceber que durante o período analisado vários comentários de teor homofóbico foram registrados nas postagens do portal Imirante no Instagram. 
O discurso de ódio no jornalismo online: análise de comentários nas redes sociais do

Portal Imirante.com

Tabela 5 - Enunciados 9, 10, 11, 12 e 13.

TÍTULO: Pabllo Vittar rompe com grife de sapatos que declarou apoio à Jair Bolsonaro. Além de Vittar, outros artistas também se posicionaram sobre o caso.
E9: "Devia romper com a vida! Se jogar de um prédio ou de um viaduto!!! Viado desgraçado!!!!"

E10: "Seria uma honra se isso fosse embora do Brasil, quando Jair Bolsonaro ganhar... Mas ele não vai não"

E11: "Desde quando esse culhão espremido canta alguma coisa..."

E12: "Pabllo vittar, eu tenho nojo de ti, viado do cão"

E13: "Rapaz doido é quem patrocina uma pessoa que tem uma voz horrível parecendo de bezerro, cara é chato e irritante demais"

Fonte: Autores.

O título da publicação direciona para uma notícia que fala que a cantora transexual Pabllo Vittar rompeu com uma grife, após esta ter declarado apoio à candidatura de Jair Bolsonaro. Assim que a postagem foi feita no Instagram do portal Imirante, a reação foi imediata.

Nos E9, E10, E11, E12 e E13, é possível ver o discurso de ódio com viés homofóbico com relação ao posicionamento de Pabllo Vittar. De acordo com Dantas e Pereira Neto (2015), essa discriminação contra LGBTs pode assumir duas formas: física ou simbólica. Essa segunda é também muito recorrente, pois, além de incitar a discriminação, ela consegue privar o sujeito de ter seus direitos de cidadão, colocando o indivíduo em uma posição de inferioridade.

O discurso homofóbico presente no E10 é nítido e sugere até mesmo que o protagonista da publicação morra "se jogando de um prédio ou de um viaduto". Essa fala dirigida a um LGBT tem a ver com a já falada violência sombólica. Esse grupo é considerado, segundo Dantas e Pereira Neto (2015), como "seres desviantes", pois discordam de uma heteronormatividade que é predominantemente cultural na sociedade.

Além do teor homofóbico, nos E9, E10, E11, E12 e E13, é possível ver a tentativa de diminuição da dignidade humana. Essa homofobia, de acordo com Dantas e Pereira Neto (2015), de uma maneira mais direta, consegue ser 
O discurso de ódio no jornalismo online: análise de comentários nas redes sociais do

Portal Imirante.com

traduzida como sendo a prática de atitudes de teor opressivo, usando também mecanismos discriminatórios, que estão associados ao preconceito e à violência.

Ainda segundo Dantas e Pereira Neto (2015), a homofobia normalmente é empregada como subsídio a uma série de ações que carregam "emoções negativas" em relação às pessoas que possuem uma orientação sexual considerada por quem realiza a prática como não normativa.

Pabllo Vittar é alvo de diversos discursos odiosos por conta da sua representatividade enquanto artista. A artista ganhou notória visibilidade nacional no ano de 2015. Desde então, muitas críticas a seu respeito sempre são lançadas. No caso da publicação analisada, muitos haters se referem a Pabllo como "isso", "viado desgraçado", "viado do cão". A carga de preconceitos que esses comentários possuem são extremos, cabendo até mesmo punições jurídicas. Entretanto, muitos não se dão conta desse direito garantido a qualquer ser humano.

O repúdio à orientação sexual de Pabllo Vittar, além de um discurso homofóbico, tem também cunho religioso. A exemplo disso, tem-se o E12, no qual o usuário chama Vittar de "viado do cão". Mais uma vez, há uma demonização do artista. Isso tem a ver com o discurso conservador de alguns usuários do Instagram, que impõe um caráter abominador à homossexualidade, de acordo com as reflexões de Dantas e Pereira Neto (2015). Dessa maneira, é possível perceber o conservadorismo defendido pelos usuários do E9 ao E13, cujo discurso revela a pureza na heterossexualidade e a impureza na homossexualidade.

Nesse ponto, observa-se, com clareza, a interdiscursividade que atravessa a formação discursiva do discurso de ódio. Novamente, há o entrecruzamento com o discurso religioso. Assim como no discurso político, o discurso homofóbico evoca o discurso religioso como forma legitimadora e balizadora dos insultos. A homossexualidade, no contexto do que pode e deve ser dito (formação discursiva) pelo discurso religioso cristão, é categorizada como postura desviante. Daí proliferam-se insultos que se utilizam de preceitos dessa formação discursiva 
O discurso de ódio no jornalismo online: análise de comentários nas redes sociais do

Portal Imirante.com

(potencialmente aceita pela sociedade), para angariar adeptos e engajamento entre os usuários da rede social.

Ainda conforme as proposições de Dantas e Pereira Neto (2015), os homossexuais, como no caso de Pabllo Vittar, são tidos por alguns como pessoas que apresentam perigo para a sociedade "tradicional", pois são vistos como "promíscuos, propagadores de doenças e pela associação com a pedofilia" (DANTAS; PEREIRA NETO, 2015, p. 6).

Sendo assim, todos os enunciados analisados sobre a publicação que se refere à cantora Pabllo Vittar, além de odiosos, carregam tom agressivo e ameaçador, enxergam a homossexualidade como uma possessão demoníaca. Portanto, é possível perceber que o discurso homofóbico praticada no mundo online, como o Instagram, no caso analisado, pouco se difere do que acontece em outros ambientes não virtuais.

\section{Discurso de ódio a artistas}

Aqui, analisa-se como os discursos de ódio estão presentes em postagens que falam sobre pessoas famosas e que possuem grande visibilidade nos cenários nacional e internacional, considerando que esse tipo de discurso não se dá apenas a figuras políticas, homossexuais ou negros.

Tabela 6 - Enunciados 14, 15, 16 e 17.

TíTULO: Fim do casamento de Anitta e Thiago Magalhães choca internet.

Fonte: Autores.
E14: "Besteira, estão caindo. Matéria nada a ver. Leitores inteligentes não gostam dessas fofoquinhas"

E15: "Quem postou essa notícia, é menino ou menina?"

E16: "Estagiários lacração. Kd o jornalismo?"

E17: "Anita??? Thiago???... Eu que pensava que o Imirante não publicava essas "baboseiras". Publica algo mais interessante! \#PQP me poupe Imirante. E eu querendo boas notícias sobre o Brasil, e vcs publicando merda! "

A publicação analisada direciona para uma notícia do Na Mira, site do portal Imirante voltado para o entretenimento. A publicação é sobre o fim do casamento da cantora Anitta e Thiago Magalhães. Embora muitos comentários 
O discurso de ódio no jornalismo online: análise de comentários nas redes sociais do

Portal Imirante.com

tenham criticado a possível "relevância" da notícia, o engajamento da publicação foi alto. Até o dia em que foi colhida para análise, 5 de outubro de 2018, a publicação tinha mais de 1.870 curtidas.

Em E14 e E17, os usuários acreditam que a notícia não tem grau de relevância dentro do portal. Além disso, classificam a publicação como "nada a ver" e garantem que "pessoas inteligentes não gostam dessas fofoquinhas". Entretanto, dentro do jornalismo moderno, o entretenimento tem ganhado cada vez mais espaço e audiência, no chamado infotainment.

O termo infotainmet surgiu nos anos de 1980, entretanto só ganhou espaço na década seguinte, quando começou a ser usado por profissionais e estudantes do campo da comunicação. Ainda de acordo com Dejavite (2007), a definição de infotainmet, assim como seu conteúdo ainda se choca em alguns conceitos que foram pré-estabelecidos no meio profissional, assim como no acadêmico. $O$ que causa esse embate é que essas novas práticas de relacionar jornalismo com entretenimento, opõe-se daquilo que separa o que seria um conteúdo sério, e de um não sério dentro da área do jornalismo.

Mas o que seria esse jornalismo sério e o não sério? Segundo as reflexões de Dejavite (2007), um jornalismo de conteúdo sério, seria aquele que se preocupa em aprofundar, investigar, criticar, além de conseguir transmitir informações atualizadas, sendo seu principal objetivo um ponto de reflexão. Já o considerado como não sério, seria aquele que tem como papel principal apenas divertir o público, com conteúdos humorísticos, e atrair a atenção e o interesse do seu receptor por meio de assuntos mais leves e amenos o que, ainda de acordo com Dejavite $(2007$, p. 3) "não traz nada de novo, apenas algo velho, com outra roupagem, que ajuda a promover ideologias, como a do consumo e a do mercado" .

Sendo assim, é notória a mudança sofrida no jornalismo. Dessa maneira, ele ganha um novo efeito que é denominado por Dejavite (2007) como "notícia light". A nova percepção em satisfazer os interesses do público receptor é algo relativamente recente, até pouco tempo ela era de pouco interesse. Contudo, em um cenário mais recente e atual, o público tem ganhado participação na escolha 
O discurso de ódio no jornalismo online: análise de comentários nas redes sociais do

Portal Imirante.com

do se a mídia vai veicular. Por isso, as empresas de cunho jornalístico têm se atentado mais em relação a seu papel dentro da sociedade.

Esse jornalismo de infotainment, como é o caso do Na Mira, dentro do portal Imirante, é o espaço destinado exatamente para estilos de vida, famosos, fofocas, que, mesmo sendo malvistos por alguns, como é o caso dos usuários do E14 ao E17, atraem, sim, o público.

De acordo com Dejavite (2007), o infotainment consegue sintetizar, de maneira direta, a intenção editorial do papel de entreter que o jornalismo também possui, cumprindo, assim, um de seus princípios mais básicos que é a de atender às necessidades de informação do seu receptor atual, seja ela de qual natureza for. Ou seja, "manifesta aquele conteúdo que informa com diversão" (DEJAVITE, 2007, p. 2).

A banalização e o menosprezo pela notícia sobre o fim do casamento de Anitta são vistos na maioria dos comentários da postagem do portal Imirante. Além disso, é possível apontar um outro discurso voltado ao profissional estagiário, representado como o responsável pela produção da matéria.

O estagiário possui um papel importante dentro de uma organização empresarial. Ele está ali para aprender e somar com a empresa. Entretanto, por muitas vezes esse profissional é descreditado pelo público pelo simples fato da sua condição enquanto estagiário.

Dentro do meio jornalístico, esse desmerecimento ao profissional estagiário, sendo ele visto como amador, sem conhecimento, que só comete falhas, pode ser visto de forma clara, como no observado em E15, onde esse descredito dado a notícia, possivelmente tem a ver com possíveis falhas cometidas pelo estagiário. Esse discurso pode ser categorizado como odioso, pois tenta desmerecer uma função profissional de alguém pelo cargo que ocupa.

Em E15 e E16, o discurso homofóbico volta a aparecer. Os usuários taxam o possível estagiário de "lacração", como acontece em E16. Em E15, ao questionar o gênero do produtor do conteúdo, o sujeito, implicitamente, evoca a carga homofóbica, já discutida nas seções anteriores. 
O discurso de ódio no jornalismo online: análise de comentários nas redes sociais do

Portal Imirante.com

No campo do jornalismo, esse teor de desqualificação dos conteúdos de "fofoca" tem suas raízes tanto nas próprias instituições, como do sendo comum dos receptores. O que pode ser taxado como sendo um "bom jornalismo", conforme os estudos de Pinto (2002), consegue ser bem representado por meio de editorias como a de política ou economia.

Dessa forma, o discurso machista aparece nos enunciados selecionados de maneira a sugerir que conteúdos de fofoca é de interesse apenas do público feminino. Esse machismo, segundo Drumont (1980, p. 81), pode ser caracterizado como sendo um sistema ideológico e que oferece formatos de identidade tanto para "elemento masculino, como para elemento feminino".

Ainda de acordo com Drumont (1980), é por meio desse modelo que é tido como "normalizante" que homem e mulher se tornam e se reafirmam como sendo "homem e mulher". Sendo assim, é possível relacionar enunciados E14, E15 e E16 também com o discurso de ódio de viés machista.

O machismo constitui, portanto, um sistema de representaçõesdominação que utiliza o argumento do sexo, mistificando assim as relações entre os homens e as mulheres, reduzindo-os a sexos hierarquizados, divididos em polo dominante e polo dominado que se confirmam mutuamente numa situação de objetos (DRUMONT, 1980, p. 82).

A seguir, outra publicação com outros comentários também de cunho odiosos pode ser viso no quadro seguinte.

Tabela 7 - Enunciados 18, 19, 20 e 21

TÍTULO: Em cerimônia íntima, William Bonner casa com fisioterapeuta Natasha Dantas. O casamento ocorreu nesse sábado (8), em São Paulo.

Fonte: Autores.

E18: "Notícia mais importante do domingo! "

E19: "Quem será a mulher reserva do Bonner?"

E20: "Zangou com o Bolsonaro e resolveu casar" E21: "A Fátima Esquerdista de meia tigela foi convidada?" 
O discurso de ódio no jornalismo online: análise de comentários nas redes sociais do

Portal Imirante.com

Nesta outra publicação, também do Na Mira, a postagem direciona para uma notícia sobre a cerimônia de casamento do jornalista Willian Bonner, da Rede Globo. Assim como na publicação sobre o fim do casamento da Anitta, os usuários questionam o grau de relevância da notícia, como em E18. Em outros comentários, como em E19, outro usuário supõe que o jornalista já tenha uma outra "esposa reserva", caso o casamento com Natasha Dantas - atual esposa do jornalista - não dê certo.

Esses discursos tentam ferir a imagem de Bonner enquanto pessoa e até mesmo como profissional. Como se observa em E19 e E20, há a tentativa de diminuí-lo por conta de um segundo casamento. Um dos aspectos do discurso religioso vai de encontro com a liberdade de expressão, pois, de acordo com o exercício de uma liberdade, não pode atingir o exercício da liberdade de uma outra pessoa. Uma carga de preconceito nesse discurso religioso usa do discurso de que um casal deve se manter unido pelo resto da vida, quem não segue isso é recriminado. Esse discurso é embasado na passagem bíblica que se encontra no evangelho de Mateus, no capítulo 19, versículo 6, que diz: "Assim, já não são dois, mas uma só carne. Portanto, não separe o homem o que Deus uniu".

No E20 também é possível ver o discurso de ódio político, insinuando que a nova união do jornalista se deu por conta de orientações do então candidato à presidência da República Jair Bolsonaro. No E21 até mesmo a ex-esposa do jornalista Willian Bonner, a também jornalista Fátima Bernardes, é alvo de ofensas de cunho político. O usuário questiona se a "esquerdista de meia tigela" foi convidada. O termo "esquerdista" nesse contexto soa como um termo pejorativo às possíveis conviç̧ões políticas de Fátima Bernardes, que em nada tem a ver com o casamento do seu ex-marido.

Ainda de acordo com Dejavite (2007, p. 3), esse tipo de conteúdo tem o poder de satisfazer a curiosidade, estimular aspirações, possibilitar extravasar as frustrações e nutrir a imaginação do público. Entretanto esse mesmo tipo de conteúdo é capaz de ativar no público os mais nocivos discursos de ódio, como vistos anteriormente. 
O discurso de ódio no jornalismo online: análise de comentários nas redes sociais do Portal Imirante.com

Um outro ponto que pode ser visto em E19 e E21 é o machismo, presente em boa parte dos comentários, porém mais visíveis nesses dois comentários, onde vê a mulher como sendo inferior ao homem, designando, assim, a figura do homem como sendo o protagonista e dominante em relação à mulher.

\section{Conclusão}

Durante as reflexões propostas neste trabalho, as escolhas teóricas para embasamento foram feitas a partir dos estudos sobre a $A D$, conforme Orlandi (2013), Fernandes (2008) e Pinto (2002). Dessa maneira, foi possível compreender as definições de discurso e suas aplicações nos âmbitos social e sociológico. A partir dessa compreensão se chegou ao foco principal do trabalho: analisar o discurso de ódio nas redes sociais. Foi tomada como recorte principal para o estudo a página do Instagram do portal Imirante.com.

A partir desse recorte, foi possível analisar teoricamente de que maneira o discurso de ódio está presente nas redes sociais. Foi possível categorizar os discursos de ódios das postagens e compreender os sistemas de relações com os quais esses discursos mantêm diálogo: discursos políticos, religiosos e sobre figuras famosas.

Como sugestões para pesquisas futuras, sugere-se o comparativo com outro portal de notícia sobre o mesmo viés analisado no Imirante.com. Isso se dá pelo fato de o Maranhão não possuir um outro veículo exclusivamente online que utilize os SRS como o Imirante.com faz. 
O discurso de ódio no jornalismo online: análise de comentários nas redes sociais do

Portal Imirante.com

\section{Referências}

BARBOSA, Suzana Oliveira. Jornalismo Digital em Ambientes Dinâmicos. Propriedades, rupturas e potencialidades do modelo JDBD. Observatório Journal, Obercom, Portugal, p. 217-244, 2008. Disponível em: http://obs.obercom.pt/index.php/obs/article/viewFile/136/138. Acesso em: 13 mar. 2018.

BRAMBILLA, Ana Maria. Jornalismo colaborativo nas redes sociais: peculiaridades e transformações de um modelo desafiador. In: PRIMO, Alex (org.). Interações em rede. Porto Alegre: Editora Meridional, 2005. p. p. 257270.

BRUGGER, Winfried. Proibição ou proteção do discurso do ódio? Algumas observações sobre o direito alemão e o americano. Direito Público, Porto Alegre, ano 4, n.15, p. 117-136, jan. /mar. 2007.

DANTAS, Monica Lucia Gomes; PEREIRA NETO, André de Faria. O discurso homofóbico nas redes sociais da internet: uma análise no facebook "Rio sem Homofobia - Grupo Público". Cadernos do Tempo Presente, São Cristóvão, SE, n. 19, p. 27-41, mar. /abr. 2015. Disponível em:

http://www6.ensp.fiocruz.br/repositorio/sites/default/files/arquivos/DiscursoHo mofobico.pdf. Acesso em: 30 out. 2018.

DEJAVITE, Fábia Angélica. A notícia light e o jornalismo de infotenimento. In: CONGRESSO BRASILEIRO DE CIÊNCIAS DA COMUNICAÇÃO, 30., 2007, Santos, SP. Anais [...]. Santos: Intercom: Sociedade Brasileira de Estudos Interdisciplinares da Comunicação, 2007. p. 1-15. Disponível em: http://www.intercom.org.br/papers/nacionais/2007/resumos/R1472-1.pdf. Acesso em: 30 out. 2018.

DIAZ, Álvaro Paul. La penalización de la incitación al odio a la luz de la jurisprudencia comparada. Revista Chilena de Derecho, Santiago de Chile, $\mathrm{CL}$, v. 38, n. 2, p. 503-609, 2011.

DRUMONT, Mary Pimentel. Elementos para uma análise do machismo.

Perspectivas, São Paulo, v. 3, p. 81-85, 1980.

EZEQUIEL, Vanderlei de Castro; CIOCCARI, Deysi. O Discurso de ódio na política contemporânea: o Trump venceu! $C \& S$, São Bernardo do Campo, v. 39, n. 3, p. 229-250, set. /dez. 2017.

FERNANDES, Cleudeumar. Análise do discurso: reflexões introdutórias. 2. ed. São Carlos: Editora Claraluz, 2008. 
O discurso de ódio no jornalismo online: análise de comentários nas redes sociais do

Portal Imirante.com

LEAL, Bruno Sousa. As estéticas do jornalismo em transformação: perspectivas de pesquisa em comunicação. In: SILVA, Gislene; KÜNSCH, Dimas A.; BERGER, Christa; ALBUQUERQUE, Afonso (org.). Jornalismo contemporâneo: figurações, impasses e perspectivas. Salvador: EDUFBA, 2011. p. 103-117.

MEYER-PFLUG, Samantha Ribeiro. Liberdade de expressão e discurso do ódio. São Paulo: Editora Revista dos Tribunais, 2009.

ORLANDI, Eni. Análise de discurso: princípios e procedimentos. São Paulo: Pontes, 2013.

PINTO, Milton José. Comunicação e discurso: introdução à análise de discursos. São Paulo: Hacker Editores, 2002.

PRIMO, Alex. Interação mútua e reativa: uma proposta de estudo. Revista FAMECOS: Mídia, Cultura e Tecnologia, Porto Alegre, RS, n. 12, p. 81-92, jun. 2000.

RECUERO, Raquel. Redes sociais na internet, difusão de informação e jornalismo: elementos para discussão. In: SOSTER, Demétrio de Azeredo; FIRMINO, Fernando (org.). Metamorfoses jornalísticas 2: a reconfiguração da forma. Santa Cruz do Sul: UNISC, 2009, v. p. 1-269. Disponível em: http://www.raquelrecuero.com/artigos.html. Acesso em: 14 abr. 2018.

RECUERO, Raquel. Redes sociais na internet. 2. ed. Porto Alegre: Sulina, 2011.

SARMENTO, Daniel. A liberdade de expressão e o problema do hate speech. Revista de Direito do Estado, Rio de Janeiro, ano 1, p. 1-58, n. 4, out. /dez. 2006.

SILVA, Rosane Leal; NICHEL, Andressa; MARTINS, Anna Clara Lehmann; BORCHARDT, Carlise Kolbe. Discurso do ódio em redes sociais: jurisprudência brasileira. Revista Direito GV, São Paulo, v. 7, n. 2, p. 445-468, jul. /dez. 2011. 